REPORTS OF MORPHOLOGY
Official Journal of the Scientific Society of Anatomists,
Histologists, Embryologists and Topographic Anatomists
of Ukraine
journal homepage: https://morphology-journal.com

\title{
Indicators of the level of subjective control in men with various
} forms of eczema

\section{Al-Omary Ala'a Osama Ahmad}

National Pirogov Memorial Medical University, Vinnytsya, Ukraine

\section{ARTICLE INFO}

Received: 15 July 2021

Accepted: 16 August 2021

UDC: $616.521-07: 616-071.2+159.922$

\section{CORRESPONDING AUTHOR}

e-mail: alaaalomari33@yahoo.com Al-Omary Ala'a Osama Ahmad

\begin{abstract}
An actual and popular area of research in psychodermatology is to conduct comprehensive studies that comprehensively reveal the mental characteristics of patients with different forms and types of eczema. This will allow in the future to optimize work with patients of this profile and to plan psychotherapeutic measures in the key of a personalized constitutional approach. The aim of the study was to examine the differences in the level of subjective control between healthy and/or eczema patients depending on the severity of dermatosis. Men aged 22 to 35 years, with a diagnosis of true ( $n=34)$ and microbial ( $n=38)$ eczema, were assessed by the level of subjective control on the basis of the J. Rotter scale edited by E.F. Bazhin et al. (1984). As a control from the data bank of the research center of National Pirogov Memorial Medical University, Vinnytsya indicators of the level of subjective control of 82 practically healthy men of the same age group were selected. Statistical processing of the results was performed in the license package "Statistica 5.5" using non-parametric evaluation methods. Patients with true eczema, compared with the control group, have a higher level of subjective control in the field of general internality, achievements, educational (professional) relations (mild course) and interpersonal relations (severe course). At patients with a microbic eczema of mild and severe course in comparison with healthy investigated size of level of subjective control is smaller in the field of failures and interpersonal relations. Patients with true eczema compared to patients with microbial eczema found significantly higher levels of subjective control in the field of general internality, failures, educational (professional) and interpersonal relationships. In patients with severe dermatosis compared with patients with mild dermatitis there is a decrease in the level of subjective control in the field of educational (professional) relations (true eczema) and interpersonal relations (microbial eczema). Thus, the peculiarities of the level of subjective control in men with various forms of eczema can serve as psychological predictors of exacerbations and exacerbations of eczema, which is certainly important for both clinicians and health care providers in particular. Keywords: true eczema, microbial eczema, indicators of the level of subjective control, men.
\end{abstract}

resistance to traditional treatments $[1,4,10,12]$.

To prevent the development of eczema with a more severe course, often one of the important conditions is the timeliness of diagnosis and treatment. However, $45.4 \%$ of patients see a doctor late, when it is difficult to achieve the effect of treatment and stable remissions [7, 8]. The question remains as to what causes such a careless attitude to the state of one's health in our society, apart from a lack of awareness. In the general population, the reluctance to seek any help from others, including medical, is closely linked to such components of subjective control 
as overestimation, shyness, distrust, suspicion, skepticism and negativism. Manifestations of increased hostility, which are also psychological risk factors for eczema and its complications, can play the role of a subjective obstacle to a timely visit to the doctor $[14,18,19]$.

It can be assumed that the severity of eczema is due to a complex set of the above and not yet specified personality and behavior, which play a pathogenetic role in the development of dermatosis, reduce willingness to therapeutic cooperation and therefore can affect not only short-term but also long-term results [9, 11]. This requires a comparative analysis of the psychological characteristics of patients with different forms and severity of eczema.

The aim of the study was to examine the differences in the level of subjective control between healthy and/or eczema patients depending on the severity of dermatosis.

\section{Materials and methods}

Men aged 22 to 35 years, with a diagnosis of true $(n=34$, including 16 mild and 18 severe) and microbial $(n=38$, including 28 mild and 10 severe) eczema, assessment of indicators of the level of subjective control based on the $J$. Rotter scale in the Research Institute named after Bekhterev and published by E.F.Bazhin et al. in 1984 [3]. This personal questionnaire is designed to diagnose internality - externality, ie the degree of readiness of a person to take responsibility for what happens to her and around her. USK_1 - indicator of the scale of general internality of the level of subjective control according to Rotter; USK_2 indicator of the level of subjective control in the field of achievements according to Rotter; USK_3 - indicator of the level of subjective control in the field of failures according to Rotter; USK_4 - an indicator of the level of subjective control in the field of family relations according to Rotter; USK_5 - an indicator of the level of subjective control in the field of educational (professional) relations according to Rotter; USK_6 - an indicator of the level of subjective control in the field of interpersonal relations according to Rotter; USK_7 is an indicator of the level of subjective control in the field of health and disease according to Rotter.

As a control from the data bank of the research center of National Pirogov Memorial Medical University, Vinnytsya indicators of the level of subjective control of 82 practically healthy men of the same age group were selected.

Statistical processing of the results was performed in the license package "Statistica 5.5" using non-parametric evaluation methods. The reliability of the difference between the values between the independent quantitative values was determined using the Mann-Whitney U-test.

\section{Results}

In practically healthy men, there is a tendency to lower values of the scale of general internality of the level of subjective control according to Rotter $(4.831 \pm 1.765)$ st. compared with men with true eczema of mild course $(5.813 \pm 2.167, p=0.089)$ st. This figure is significantly higher

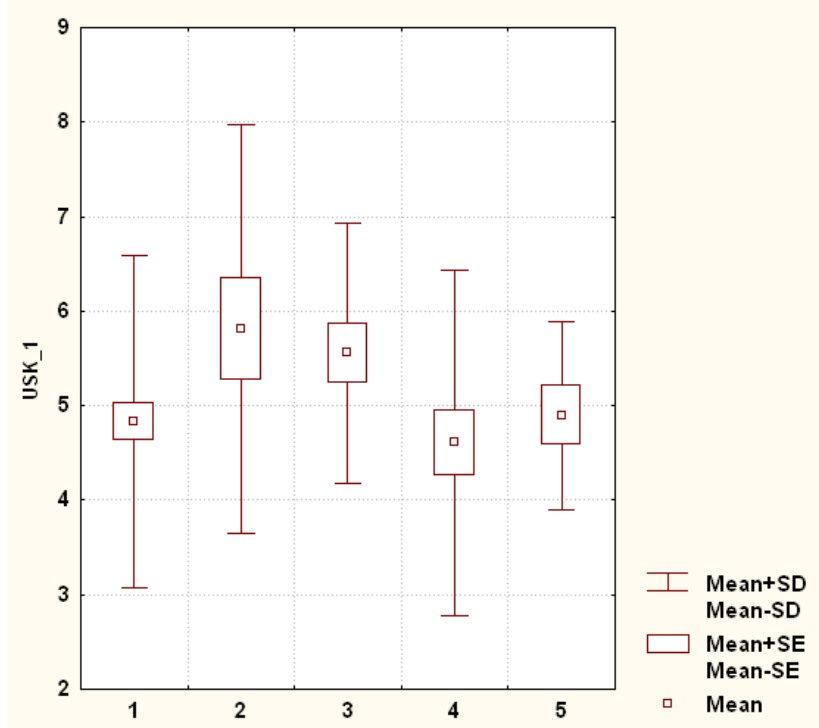

Fig. 1. The magnitude of the scale of general internality of the level of subjective control according to Rotter (USK_1) in healthy and sick men with various forms of eczema (st.).

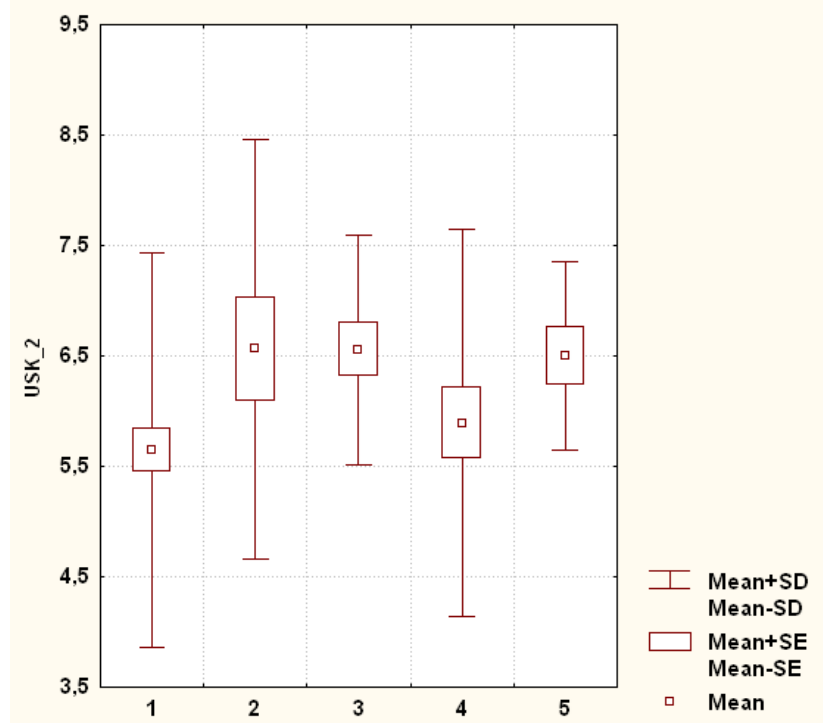

Fig. 2. The value of the indicator of the level of subjective control in the field of achievement according to Rotter (USK_2) in healthy and sick men with various forms of eczema (st.).

in patients with true eczema of severe course $(5.556 \pm 1.381$; $\mathrm{p}<0.05)$ st. and tends to greater values in patients with true eczema of mild course $(5.813 \pm 2.167, p=0.085)$ st. compared with those studied with mild microbial eczema (4.607 \pm 1.833 ) st. (Fig. 1).

The indicator of the level of subjective control in the field of achievements according to Rotter is significantly higher in patients with true eczema of severe course $(6.556 \pm 1.042 ; p<0.05)$ st. and tends to greater values in patients with true eczema of mild course $(6.563 \pm 1.896$, $\mathrm{p}=0.066)$ st. compared with practically healthy subjects (5.649 \pm 1.783 ) st. (Fig. 2). 


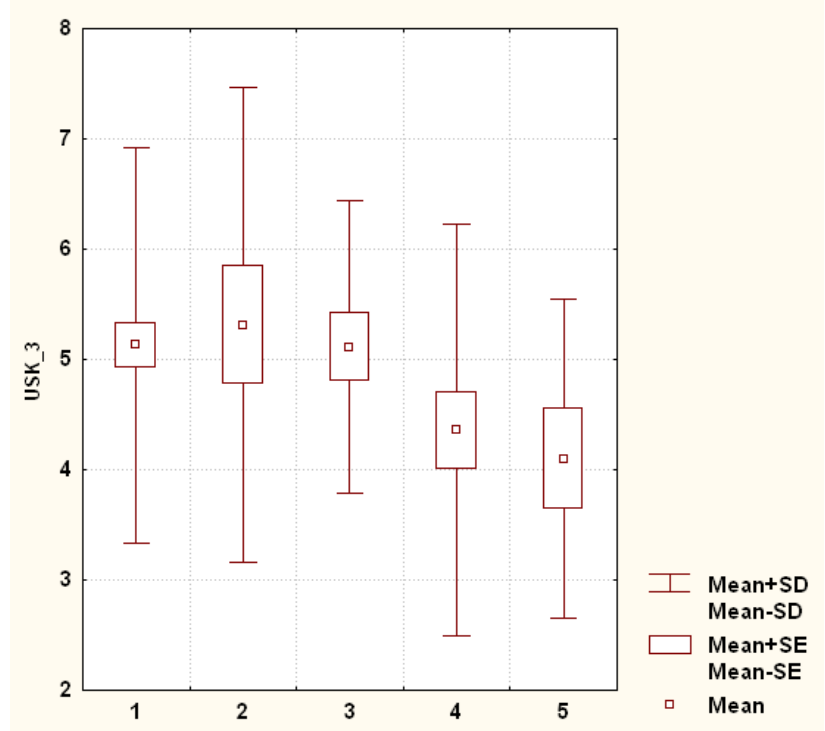

Fig. 3. The value of the level of subjective control in the field of failures according to Rotter (USK_3) in healthy and sick men with various forms of eczema (st).

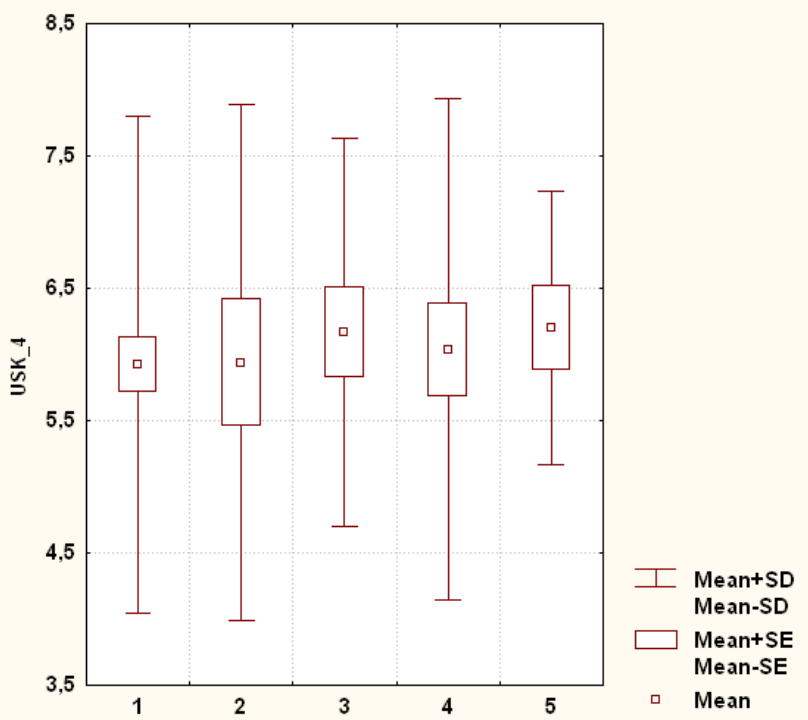

Fig. 4. The value of the level of subjective control in the field of family relations according to Rotter (USK_4) in healthy and choral men with various forms of eczema (st.).

The indicator of the level of subjective control in the field of failures according to Rotter is significantly lower in patients with microbial eczema of mild course $(4.357 \pm 1.870 ; p<0.05)$ st. and tends to lower values in patients with severe microbial eczema (4.100 \pm 1.499 , $\mathrm{p}=0.098)$ st. compared with practically healthy subjects $(5.130 \pm 1.794)$ st. This indicator tends to be higher in patients with true eczema of severe course $(5.111 \pm 1.323$; $\mathrm{p}=0.057$ ) st. and in patients with true eczema of mild course (5.313 $\pm 2.152, p=0.097)$ st. compared with those studied with mild microbial eczema (4.357 \pm 1.870$)$ st. (Fig. 3).

The indicator of the level of subjective control in the field of family relations according to Rotter has no reliable and tends to differ between healthy and/or eczema patients depending on the severity of dermatosis (Fig. 4).

The indicator of the level of subjective control in the field of educational (professional) relations according to Rotter is significantly higher in patients with true eczema of mild course $(5.313 \pm 1.401 ; p<0.01)$ st. compared with almost healthy subjects $(4.104 \pm 1.527)$ st. This figure is significantly higher in patients with true eczema of mild course $(5.313 \pm 1.401 ; p<0.05-0.001)$ st. compared with patients with true eczema of severe course $(4.389 \pm 1.378)$

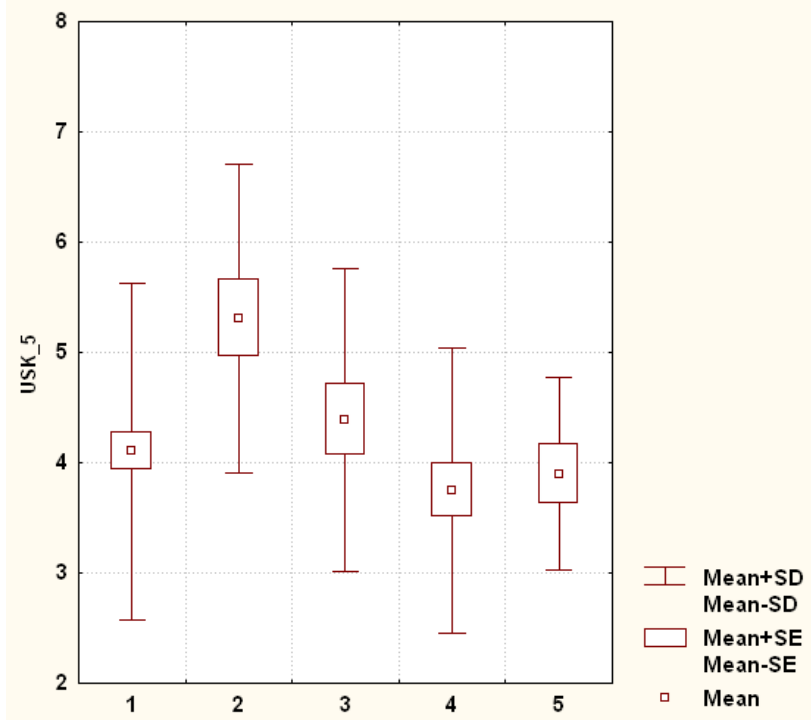

Fig. 5. The value of the indicator of the level of subjective contro in the field of educational (professional) relations according to Rotter (USK_5) in healthy and sick men with various forms of eczema (st.).

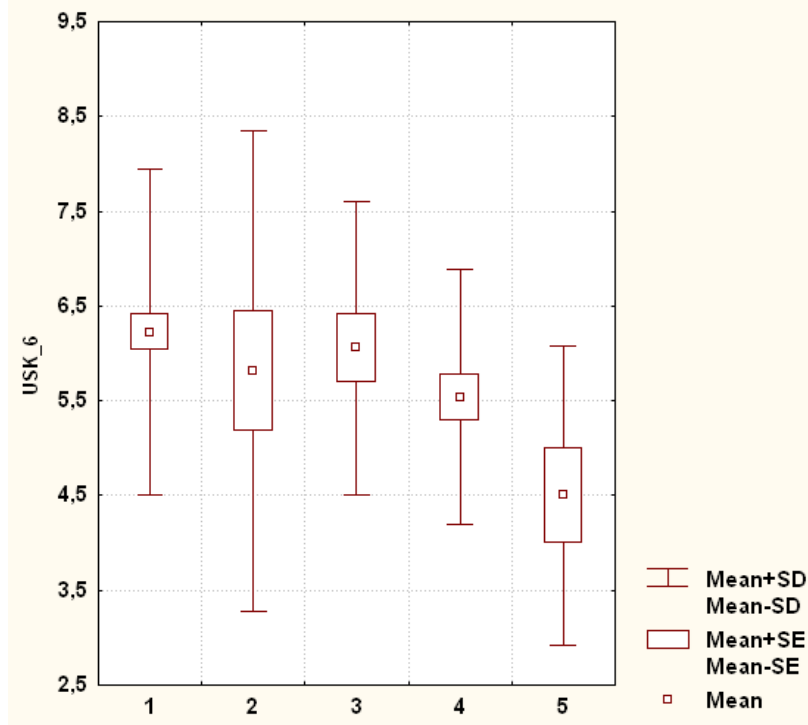

Fig. 6. The value of the level of subjective control in the field of interpersonal relations according to Rotter (USK_6) in healthy and sick men with various forms of eczema (st.). 


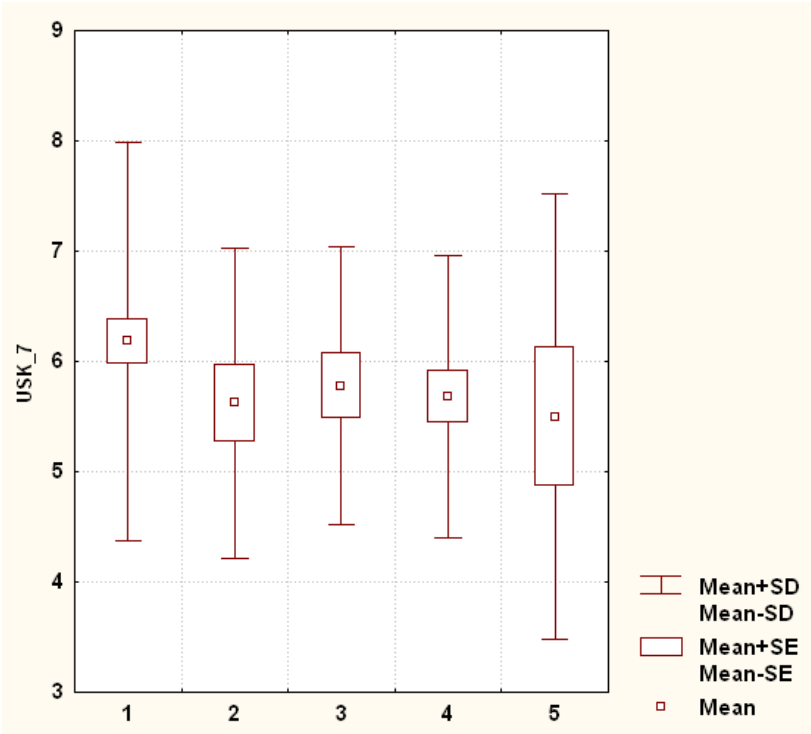

Fig. 7. The value of the indicator of the level of subjective control in the field of health and disease according to Rotter (USK_7) in healthy and sick men with various forms of eczema (st.).

st., studied with microbial eczema of mild $(3.750 \pm 1.295)$ st. and severe (3.900 \pm 1.876$)$ st. course (Fig. 5).

The indicator of the level of subjective control in the field of interpersonal relations according to Rotter is significantly lower in patients with microbial eczema of the mild $(5.536 \pm 1.347 ; p<0.05)$ st. and severe $(4.500 \pm 1.581$; $\mathrm{p}<0,01)$ st. course in comparison with practically healthy subjects $(6.221 \pm 1.722)$ st. This figure is significantly higher in patients with true eczema of severe course $(6.056 \pm 1.552$; $\mathrm{p}<0.01)$ st. and tends to be higher in patients with truth (5.813 $\pm 2.536 ; p=0.078)$ st. and microbial (5.536 \pm 1.347 ; $p=0.071)$ st. eczema of mild course in comparison with patients with a severe form of microbial eczema

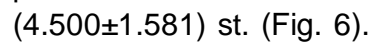

The indicator of the level of subjective control in the field of health and disease according to Rotter have no significant and tends to differ when comparing healthy and/ or patients with eczema depending on the severity of dermatosis (Fig. 7).

\section{Discussion}

In recent decades, the world has seen a sharp increase in the number of people suffering from various forms of eczema $[2,15]$. In the case of severe and often recurrent dermatosis there is the destruction of normal activities and attitudes of the individual. Groups with a more severe course of the disease feel that they have little control over their lives, including little control over their health, which reflects the reality of helplessness and limited access to health care. As part of the process of learning helplessness, this situation may well lead to a fairly stable orientation, similar to personality traits. The problem of a person in a situation of severe disease should be considered not only as a medical but also as a social and psychological problem
$[13,16]$.

Currently, there are a number of studies in psychodermatology, but their results remain contradictory due to the lack of comprehensive studies that comprehensively reveal the mental characteristics of patients with different forms and types of eczema [5, 17, 20]. Our test position, which can be verified, states that the expressed locus of control will be significantly different when compared between healthy and sick subjects and between patients with different forms and course of eczema. We expect healthy individuals and patients with mild dermatosis to be more likely to have more control over important aspects of their lives and health.

According to our results, we see that in healthy subjects and in patients with true eczema with mild and severe course dominate internal locus of control, clearly expressed on the scales of internality-externality (except USK_5 in severe true eczema). Moreover, compared with the control group in the mild course of true eczema in size is dominated by USK_1, USK_2 and USK_5, and in severe true eczema - USK_2. All this means the self-confidence of the subjects, more calm and friendly, with a more positive system of relationships and a greater awareness of meaning and purpose in life.

The internal locus of control USK_1, USK_3 and USK_5 in patients with mild microbial eczema and USK_1, USK_3, USK_5 and USK_ 6 deviates to the left of normal $(<\overline{5} .5$ stens), indicating an external type of subjective control in these areas of life. Such people do not see a connection between their actions and significant events in their lives, do not consider themselves able to control their development and believe that most of them are the result of chance or actions of other people. Subjects tend to attribute responsibility for such events to other people or consider them the result of bad luck. They tend to attach more importance to external circumstances - management, co-workers, luck - failure. And in patients with severe microbial eczema, a low USK_ 6 indicates that they do not consider themselves able to actively form their circle of communication and tend to consider their relationship the result of their partners.

Significantly higher levels of subjective control over USK_3 and USK_6 were found in healthy subjects compared with patients with mild and severe microbial eczema.

A comparison between groups with a similar form and different degrees of severity of dermatosis revealed significantly higher levels of subjective control in the mild form of true and microbial eczema, respectively, for USK_5 and USK_6.

It is noteworthy that, regardless of the severity of the course, patients with true eczema have significantly greater differences and trends in the level of subjective control compared with patients with mild and severe microbial eczema. Thus, patients with true eczema have higher values: 
USK_1, USK_3 and USK_5 (mild) and USK_6 (severe) compared to microbial eczema with similar severity;

USK_5 and USK_6 (mild) compared with severe microbial eczema and USK_1 and USK_3 (severe) compared with mild microbial eczema.

Summarizing the results of the study, we note that patients with true eczema with different currents are characterized as a pronounced internal personality with features of externality, characterize themselves as good, independent, fair and partially decisive. Patients with microbial eczema showed dependence on external circumstances - environmental conditions, other people's actions, accidents. They have a low level of subjective control, although they soberly assess the situation of their health and the immediate environment. Subjects do not consider their actions an important factor in the organization of their own production activities, in complex relationships in the team, in their promotion. Thus, in a comparative study of the level of subjective control over different areas of life between healthy and/or patients with eczema depending on the severity of dermatosis, an idea of the content of the disease, revealed the psychological characteristics of patients (phenotypic manifestation), which can be used to

\section{References}

[1] Ban, L., Langan, S.M., Abuabara, K., Thomas, K.S., Sultan, A.A., Sach, T. ... Ratib, S. (2018). Incidence and sociodemographic characteristics of eczema diagnosis in children: a cohort study. Journal of Allergy and Clinical Immunology, 141(5), 1927-1929. doi: 10.1016/ j.jaci.2017.12.997

[2] Barbarot, S., Auziere, S., Gadkari, A., Girolomoni, G., Puig, L., Simpson, E.L. ... Eckert, L. (2018). Epidemiology of atopic dermatitis in adults: results from an international survey. Allergy, 73(6), 1284-1293. doi: 10.1111/all.13401

[3] Bazhin, E.F., Golynkina, E.A., \& Etkind, A.M. (1984). Метод исследования уровня субъективного контроля [Method for researching the level of subjective control]. Психологический журнал - Psychological Journal, 5(3), 152-162.

[4] Brunner, P.M., \& Guttman-Yassky, E. (2019). Racial differences in atopic dermatitis. Annals of Allergy, Asthma \& Immunology, 122(5), 449-455. doi: 10.1016/j.anai.2018.11.015

[5] Dalgard, F.J., Gieler, U., Tomas-Aragones, L., Lien, L., Poot, F., Jemec, G.B. ... Kupfer, J. (2015). The psychological burden of skin diseases: a cross-sectional multicenter study among dermatological out-patients in 13 European countries. Journal of Investigative Dermatology, 135(4), 984-991. doi: 10.1038/ jid.2014.530

[6] de Lusignan, S., Alexander, H., Broderick, C., Dennis, J., McGovern, A., Feeney, C., \& Flohr, C. (2020). Epidemiology and management of atopic dermatitis in England: an observational cohort study protocol. BMJ Open, 10(9), e037518. doi: 10.1136/bmjopen-2020-037518

[7] de Lusignan, S., Alexander, H., Broderick, C., Dennis, J., McGovern, A., Feeney, C., \& Flohr, C. (2021). Patterns and trends in eczema management in UK primary care (20092018): A population-based cohort study. Clinical \& Experimental Allergy, 51(3), 483-494. doi: 10.1111/cea.13783

[8] Drucker, A.M., Wang, A.R., Li, W.Q., Sevetson, E., Block, J.K., \& Qureshi, A.A. (2017). The burden of atopic dermatitis: summary optimize work with patients of this profile, as well as in the framework of rehabilitation for psychotherapeutic measures in the key of a personalized constitutional approach.

\section{Conclusion}

1. Compared with healthy subjects, patients with true eczema have a higher level of subjective control in the field of general internality, achievements, educational (professional) relations (easy course) and interpersonal relations (severe course). In patients with microbial eczema, the opposite situation is observed: compared with the control group in mild and severe course, the value of the studied indicator is smaller in the field of failures and interpersonal relationships.

2. Patients with true eczema differ significantly from patients with microbial eczema by higher levels of subjective control in the field of general internality, failures, educational (professional) and interpersonal relationships.

3. Decreased level of subjective control in the field of educational (professional) relations (truth of eczema) and interpersonal relations (microbial eczema) distinguishes patients with severe dermatosis from patients with mild.

of a report for the National Eczema Association. Journal of Investigative Dermatology, 137(1), 26-30. doi: 10.1016/ j.jid.2016.07.012

[9] Ersser, S.J., Cowdell, F., Latter, S., Gardiner, E., Flohr, C., Thompson, A. R. ... Drury, A. (2014). Psychological and educational interventions for atopic eczema in children. Cochrane Database of Systematic Reviews, (1), CD004054. doi: 10.1002/14651858.CD004054.pub3

[10] Fuxench, Z.C.C., Block, J.K., Boguniewicz, M., Boyle, J., Fonacier, L., Gelfand, J.M. ... Ong, P.Y. (2019). Atopic dermatitis in America study: a cross-sectional study examining the prevalence and disease burden of atopic dermatitis in the US adult population. Journal of Investigative Dermatology, 139(3), 583-590. doi: 10.1016/j.jid.2018.08.028

[11] Gieler, U., Gieler, T., Peters, E.M.J., \& Linder, D. (2020). Skin and Psychosomatics-Psychodermatology today. JDDG: Journal der Deutschen Dermatologischen Gesellschaft, 18(11), 1280-1298. doi: 10.1111/ddg.14328

[12] Kaufman, B.P., Guttman-Yassky, E., \& Alexis, A.F. (2018). Atopic dermatitis in diverse racial and ethnic groups - Variations in epidemiology, genetics, clinical presentation and treatment. Experimental Dermatology, 27(4), 340-357. doi: 10.1111/ exd. 13514

[13] Kimball, A.B., \& Linder, M.D. (Eds.). (2013). Dermatological Diseases and Cumulative Life Course Impairment (Vol. 44). Karger Medical and Scientific Publishers.

[14] Le Roux, E., Powell, K., Banks, J.P., \& Ridd, M.J. (2018). GPs' experiences of diagnosing and managing childhood eczema: a qualitative study in primary care. British Journal of General Practice, 68(667), e73-e80. doi: 10.3399/bjgp18X694529

[15] Lim, H.W., Collins, S.A., Resneck Jr, J.S., Bolognia, J.L., Hodge, J.A., Rohrer, T.A. ... Moyano, J.V. (2017). The burden of skin disease in the United States. Journal of the American Academy of Dermatology, 76(5), 958-972.

[16] Schut, C., Bosbach, S., Gieler, U., \& Kupfer, J. (2014). Personality 
traits, depression and itch in patients with atopic dermatitis in an experimental setting: a regression analysis. Acta Dermatovenereologica, 94(1), 20-25. doi: 10.2340/00015555-1634

[17] Schut, C., Weik, U., Tews, N., Gieler, U., Deinzer, R., \& Kupfer, J. (2015). Coping as mediator of the relationship between stress and itch in patients with atopic dermatitis: a regression and mediation analysis. Experimental Dermatology, 24(2), 148-150. doi: 10.1111/exd.12578

[18] Shi, V.Y., Nanda, S., Lee, K., Armstrong, A.W., \& Lio, P.A.
(2013). Improving patient education with an eczema action plan: a randomized controlled trial. JAMA Dermatology, 149(4), 481-483. doi: 10.1001/jamadermatol.2013.2143

[19] Tanei, R., \& Hasegawa, Y. (2016). Atopic dermatitis in older adults: a viewpoint from geriatric dermatology. Geriatrics \& Gerontology International, 16(1), 75-86. doi: 10.1111/ggi.12771

[20] Wise, T.N. (2014). Psychosomatics: past, present and future. Psychotherapy and Psychosomatics, 83(2), 65-69. doi: $10.1159 / 000356518$

\section{ОСОБЛИВОСТІ ПОКАЗНИКІВ РІВНЯ СУБ'ЄКТИВНОГО КОНТРОЛЮ У ЧОЛОВІКІВ, ХВОРИХ НА РІЗНІ ФОРМИ ЕКЗЕМИ Аль-Омарі Ала'а Осама Ахмад}

Актуальним і затребуваним напрямком досліджень в психодерматології є проведення комплексних досліджень, які різнобічно розкривають психічні особливості пацієнтів з різними формами і типом перебігу екземи. Це дозволить у майбутньому оптимізувати роботу з хворими даного профілю та спланувати психотерапевтичні заходи в ключі персоніфікованого конституціонального підходу. Мета дослідження - вивчити відмінності показників рівня суб'єктивного контролю між здоровими та/або хворими на екзему в залежності від тяжкості перебігу дерматоза. Чоловікам віком від 22 до 35 років, з діагнозом істинної (n=34) та мікробної (n=38) екземи, проведено оцінку показників рівня суб'єктивного контролю на основі шкали Дж. Роттера за редакцією Є.Ф.Бажина зі співавторами (1984). В якості контролю з банку даних науково-дослідного центру Вінницького національного медичного університету ім. М.І.Пирогова були відібрані показники рівня суб'єктивного контролю 82 практично здорових чоловіків аналогічної вікової групи. Статистичну обробку результатів проведено в ліцензійному пакеті "Statistica 5.5" з використанням непараметричних методів оцінки. У хворих на істинну екзему порівняно із групою контролю відмічається більший рівень суб'єктивного контролю в області загальної інтернальності, досягнень, навчальних (професійних) відносин (легкий перебіг) і міжособистісних відносин (тяжкий перебіг). У хворих на мікробну екзему легкого і тяжкого перебігу, порівняно зі здоровими досліджуваними, величина рівня суб'єктивного контролю менша в області невдач і міжособистісних відносин. У хворих на істинну екзему, порівняно із пацієнтами з мікробною екземою, встановлено достовірно вищі показники рівня суб'єктивного контролю в області загальної інтернальності, невдач, навчальних (професійних) і міжособистісних відносин. У хворих з тяжким перебігом дерматоза, порівняно із пацієнтами з легким перебігом, відмічається зниження рівня суб'єктивного контролю в області навчальних (професійних) відносин (істинна екзема) і міжособистісних відносин (мікробна екзема). Таким чином, особливості показників рівня суб'єктивного контролю у чоловіків, хворих на різні фрорми екземи, слугуватимуть в якості психологічних предикторів випадків загострення $і$ поважчання екземи, що безумовно важливо як для клініцистів, так і організаторів охорони здоров'я зокрема.

ключові слова: істинна екзема, мікробна екзема, показники рівня суб'єктивного контролю, чоловіки. 